\title{
Changes in biomass and chemical composition during lecithotrophic larval development of the southern king crab, Lithodes santolla (Molina)
}

\author{
Gustavo A. Lovrich ${ }^{\mathrm{a}, *}$, Sven Thatje ${ }^{\mathrm{b}}$, Javier A. Calcagno ${ }^{\mathrm{c}}$, \\ Klaus Anger ${ }^{\mathrm{d}}$, Antje Kaffenberger ${ }^{\mathrm{d}}$ \\ ${ }^{a}$ Consejo Nacional de Investigaciones Cientificas y Técnicas, Centro Austral de Investigaciones Cientificas, \\ CADIC, CC 92, V9410BFD Ushuaia, Tierra del Fuego, Argentina \\ ${ }^{\mathrm{b}}$ Alfred Wegener Institute for Polar and Marine Research, PO Box 120 161, \\ D-27515 Bremerhaven, Germany \\ ${ }^{\mathrm{c}}$ Universidad de Buenos Aires, Facultad de Ciencias Exactas y Naturales, Intendente Güiraldes 2160 , \\ Lab 64, $4^{\text {to }}$ Piso, Pab II, Ciudad Universitaria C1428EHA, Buenos Aires, Argentina \\ ${ }^{\mathrm{d}}$ Biologische Anstalt Helgoland, Stiftung Alfred Wegener Institute for Polar and Marine Research, \\ Helgoland, Germany
}

Received 13 September 2002; received in revised form 8 November 2002; accepted 5 December 2002

\begin{abstract}
Changes in biomass and elemental composition (dry mass, $W$; carbon, $\mathrm{C}$; nitrogen, N; hydrogen, $\mathrm{H})$ were studied in the laboratory during complete larval and early juvenile development of the southern king crab, Lithodes santolla (Molina), formerly known as Lithodes antarcticus (Jacquinot). At $6 \pm 0.5{ }^{\circ} \mathrm{C}$, total larval development from hatching to metamorphosis lasted about 10 weeks, comprising three demersal zoeal stages and a benthic megalopa, with mean stage durations of 4,7 , 11 and 47 days, respectively. No differences in development duration or mortality were observed in larvae either fed with Artemia sp. nauplii or unfed, indicating that all larval stages of L. santolla are lecithotrophic. First feeding and growth were consistently observed immediately after metamorphosis to the first juvenile crab stage. Regardless of the presence or absence of food, $W, \mathrm{C}, \mathrm{N}$ and $\mathrm{H}$ decreased throughout larval development. Also the C:N mass ratio decreased significantly, from 7.7 at hatching to 4.1 at metamorphosis, indicating that a large initial lipid store remaining from the egg yolk was gradually utilized as an internal energy source, while proteins played a minor role as a metabolic substrate. In total, $56-58 \%$ of the initial quantities of $\mathrm{C}$ and $\mathrm{H}$ present at hatching, and $20 \%$ of $\mathrm{N}$ were lost during nonfeeding larval development to metamorphosis. Nine to ten percent of the initially present $\mathrm{C}, \mathrm{N}$ and $\mathrm{H}$ were lost with larval exuviae, half of these losses occurring in the three zoeal stages combined and another half in the megalopa stage alone. Metabolic biomass
\end{abstract}

\footnotetext{
* Corresponding author. Tel.: +54-2901-422278; fax: +54-2901-430644.
}

E-mail address: lovrich@tierradelfuego.org.ar (G.A. Lovrich). 
degradation accounted for losses of about $47-50 \%$ in $\mathrm{C}$ and $\mathrm{H}$ but for only $10 \%$ in N. Hence, most of the losses in $\mathrm{C}$ and $\mathrm{H}$ reflected metabolic energy consumption (primarily lipid degradation), while about half of the losses in $\mathrm{N}$ and two thirds of those in $W$ were due to larval exuviation. Complete independence from food throughout larval development is based on an enhanced maternal energy investment per offspring and on energy-saving mechanisms such as low larval locomotory activity and low exuvial losses. These traits are interpreted as bioenergetic adaptations to food-limited conditions in Subantarctic regions, where a pronounced seasonality of day length limits the period of primary production, while low temperatures enforce a long duration of pelagic development.

(C) 2003 Elsevier Science B.V. All rights reserved.

Keywords: Cold adaptation; Crustacea; Larval development; Lecithotrophy; Lithodidae; Reproductive strategies

\section{Introduction}

Lithodid crabs, in general, represent an important fishery target in cold and temperate regions of both hemispheres, and, as a consequence of their commercial value, an extensive literature is available on their growth, feeding, taxonomy and fisheries management (for references, see Dawson, 1989; Lovrich, 1997). The southern king crab, Lithodes santolla (Molina), formerly known as Lithodes antarcticus (Jacquinot), is a typical example, constituting an important part of the local artisanal trap fishery in the Argentine and Chilean parts of Tierra del Fuego, the Strait of Magellan, and in adjacent channels and fjords (Campodonico, 1971; Lovrich, 1997).

In contrast to the biology of adult lithodids, that of the early life-cycle stages has remained scarcely known (Nakanishi, 1985; Anger, 1996). Several studies have paid attention to the larval morphology, development and ecology of L. santolla (Campodonico, 1971; Vinuesa et al., 1985; Comoglio and Vinuesa, 1991; Amin et al., 1998; Lovrich and Vinuesa, 1996, 1999; Lovrich, 1999; McLaughlin et al., 2001), while no information has been available on changes in biomass and chemical composition during larval development. In a previous investigation on a congener, the northern king crab (Lithodes maja), decreasing biomass values in both fed and unfed larvae indicated a completely endotrophic mode of development (Anger, 1996). Based on similarities in several larval traits (e.g. three zoeal stages and big yolky larvae), the author suggested that the southern king crab may show the same mode of development, tentatively interpreting their lecithotrophy as an adaptation to planktonic food limitation in high latitudes. In the present study, we analysed the role of external food for larval and early juvenile development in L. santolla, comparing changes in dry mass and in the contents of organically bound elements (carbon, nitrogen, hydrogen) of fed and unfed larvae.

\section{Materials and methods}

\subsection{Capture and maintenance of ovigerous females}

Ovigerous females of L. santolla were caught in April 2000 from ca. 15 to $30 \mathrm{~m}$ depths in the Beagle Channel $\left(54^{\circ} 53.8^{\prime} \mathrm{S}, 68^{\circ} 17.0^{\prime} \mathrm{W}\right)$ using commercial fishery traps. The crabs 
were kept in aquaria at $6 \pm 0.5{ }^{\circ} \mathrm{C}$ in the local institute "Centro Austral de Investigaciones Científicas" (CADIC) in Ushuaia, Argentina. In May, they were transported on board the German scientific research vessel PFS Polarstern to Bremerhaven and subsequently to the marine biological laboratory Helgoland, Germany. During this transport, which took about 1 month, water was changed three times a week and food (squid) was given twice a week. The maintenance of females and, later, the rearing of larvae took place under constant conditions of temperature $\left(6 \pm 0.5{ }^{\circ} \mathrm{C}\right)$ and salinity $(32 \%$ o $)$, with an artificial $12: 12-\mathrm{h}$ light/dark cycle. The ovigerous females were kept individually in flow-through tanks with at least 101 seawater.

\subsection{Rearing of larvae and juveniles}

Freshly hatched larvae were collected in filters receiving the overflow from the aquaria. Since most larvae hatched at night, samples were taken every morning. Filters were cleaned every evening to ensure that larval age did not vary more than by $12 \mathrm{~h}$.

Actively moving larvae were randomly selected and kept in individual bowls with about $100 \mathrm{ml}$ seawater. In one treatment, the larvae were reared from hatching through to metamorphosis in complete absence of food, while in a second treatment, the larvae were fed with freshly hatched Artemia nauplii (Argent Chemical Laboratories, USA). In this experiment, we sampled megalopae and juvenile crabs only once each, at the beginning of their moulting cycles.

In another experiment, larvae from the same female were reared without food until they reached the megalopa stage. Subsequently, changes in biomass and chemical composition were studied with a higher temporal resolution throughout the megalopa and crab I stages, comparing again a fed and an unfed group in the megalopa; juveniles were always fed.

The larvae were checked daily for deaths or moults, and shed exuviae were sampled for later analyses of lost biomass (see below). Water was changed every 2 days and, where appropriate, food was supplied.

The larvae passed invariably through three zoeal stages and one megalopa. The separation of the different stages was done on the basis of an appearing exuvia and morphological changes in the larvae (Campodonico, 1971; McLaughlin et al., 2001). The zoeal II differs from the first stage in the presence of small but conspicuous pleopod buds. The zoea III shows developed but still nonfunctional pleopods.

When larvae reached the benthic megalopa, a piece of nylon mesh was placed in each bowl as an artificial substrate, which facilitated the settlement and metamorphosis of the megalopa.

\subsection{Sampling for elemental and biochemical analyses}

All larvae sampled from the first experiment for elemental and biochemical analyses originated from the same female. Larvae from a second female were used to study biomass changes in the megalopa and first juvenile. Samples for determinations of dry mass $(W)$ and elemental composition $(\mathrm{C}, \mathrm{N}, \mathrm{H}$; with $n=5$ replicates each; one individual per replicate) were taken immediately after hatching and in variable intervals during later development (see Table 1). Exuviae were sampled from each larval stage in order to 
Table 1

L. santolla. Changes in dry mass $(W)$ and contents of carbon $(\mathrm{C})$, nitrogen $(\mathrm{N})$ and hydrogen $(\mathrm{H})($ all in $\%$ of $W ; \bar{x} \pm \mathrm{S} . \mathrm{D}$.) during larval development in presence or absence of food (Artemia sp.) and during growth of the first juvenile crab stage (always fed); age given in days (a) within each stage and (b) after hatching

\begin{tabular}{|c|c|c|c|c|c|c|c|c|c|c|c|c|c|c|c|c|c|c|}
\hline \multirow[t]{3}{*}{ Stage } & \multicolumn{2}{|c|}{ Age } & \multicolumn{4}{|c|}{$W(\mu \mathrm{g} /$ individual $)$} & \multicolumn{4}{|c|}{$\mathrm{C}(\%$ of $W)$} & \multicolumn{4}{|c|}{$\mathrm{N}(\%$ of $W)$} & \multicolumn{4}{|c|}{$\mathrm{H}(\%$ of $W)$} \\
\hline & \multirow[t]{2}{*}{ (a) } & \multirow[t]{2}{*}{ (b) } & \multicolumn{2}{|c|}{ With Artemia } & \multicolumn{2}{|c|}{ Without Artemia } & \multicolumn{2}{|c|}{ With Artemia } & \multicolumn{2}{|c|}{ Without Artemia } & \multicolumn{2}{|c|}{ With Artemia } & \multicolumn{2}{|c|}{ Without Artemia } & \multicolumn{2}{|c|}{ With Artemia } & \multicolumn{2}{|c|}{ Without Artemia } \\
\hline & & & $\bar{x}$ & \pm S.D. & $\bar{x}$ & \pm S.D. & $\bar{x}$ & \pm S.D. & $\bar{x}$ & \pm S.D. & $\bar{x}$ & \pm S.D. & $\bar{x}$ & \pm S.D. & $\bar{x}$ & \pm S.D. & $\bar{x}$ & \pm S.D. \\
\hline \multirow[t]{2}{*}{ Zoea I } & 0 & 0 & 1017 & 76 & 1017 & 76 & 54.5 & 0.7 & 54.5 & 0.7 & 7.1 & 0.2 & 7.1 & 0.2 & 8.2 & 0.1 & 8.2 & 0.1 \\
\hline & 4 & 4 & 1002 & 13 & 957 & 69 & 55.3 & 0.4 & 55.1 & 0.6 & 7.4 & 0.1 & 7.4 & 0.1 & 8.5 & 0.1 & 8.4 & 0.1 \\
\hline Zoea II & 0 & 5 & 920 & 61 & 958 & 62 & 54.0 & 0.7 & 54.7 & 1.1 & 7.2 & 0.2 & 7.2 & 0.2 & 8.1 & 0.1 & 8.4 & 0.2 \\
\hline Zoea III & 0 & 11 & 930 & 34 & 882 & 94 & 51.7 & 0.9 & 51.7 & 1.0 & 7.5 & 0.2 & 7.7 & 0.3 & 8.0 & 0.2 & 8.0 & 0.1 \\
\hline \multirow[t]{5}{*}{ Megalopa } & 0 & 22 & 821 & 44 & 768 & 70 & 50.7 & 0.5 & 50.5 & 0.7 & 8.2 & 0.3 & 8.0 & 0.3 & 7.8 & 0.1 & 7.5 & 0.1 \\
\hline & 10 & 32 & 938 & 111 & 914 & 96 & 42.2 & 2.7 & 41.6 & 0.8 & 7.0 & 0.4 & 7.2 & 0.1 & 6.2 & 0.4 & 6.1 & 0.1 \\
\hline & 20 & 42 & 869 & 113 & 883 & 90 & 37.7 & 0.6 & 38.8 & 1.3 & 6.8 & 0.2 & 7.3 & 0.3 & 5.5 & 0.1 & 5.6 & 0.2 \\
\hline & 30 & 52 & 944 & 55 & 868 & 101 & 35.5 & 2.0 & 35.4 & 1.9 & 6.9 & 0.2 & 6.9 & 0.0 & 5.2 & 0.3 & 5.1 & 0.3 \\
\hline & 40 & 62 & 765 & 40 & 747 & 60 & 35.3 & 0.8 & 36.8 & 1.2 & 7.9 & 0.3 & 8.3 & 0.3 & 5.0 & 0.2 & 5.2 & 0.2 \\
\hline \multirow[t]{10}{*}{ Crab I } & 0 & 66 & 666 & 82 & 561 & 168 & 40.4 & 3.7 & 39.3 & 1.6 & 8.4 & 0.8 & 8.9 & 0.6 & 5.9 & 0.6 & 5.6 & 0.3 \\
\hline & 2 & 68 & 801 & 176 & & & 36.1 & 9.6 & & & 7.1 & 1.6 & & & 5.0 & 1.4 & & \\
\hline & 5 & 71 & 1385 & 190 & & & 26.1 & 0.8 & & & 4.7 & 0.2 & & & 3.4 & 0.1 & & \\
\hline & 10 & 76 & 1722 & 116 & & & 24.9 & 0.6 & & & 4.3 & 0.2 & & & 3.2 & 0.1 & & \\
\hline & 15 & 81 & 1677 & 66 & & & 26.0 & 1.7 & & & 4.6 & 0.1 & & & 3.4 & 0.3 & & \\
\hline & 20 & 86 & 1794 & 98 & & & 27.4 & 0.5 & & & 4.9 & 0.1 & & & 3.5 & 0.1 & & \\
\hline & 25 & 91 & 2008 & 150 & & & 28.2 & 0.9 & & & 5.1 & 0.1 & & & 3.6 & 0.2 & & \\
\hline & 30 & 96 & 1826 & 336 & & & 27.3 & 2.1 & & & 5.0 & 0.4 & & & 3.5 & 0.3 & & \\
\hline & 35 & 101 & 1998 & 92 & & & 28.1 & 0.7 & & & 5.4 & 0.1 & & & 3.7 & 0.1 & & \\
\hline & 40 & 106 & 1732 & 201 & & & 27.8 & 1.5 & & & 5.5 & 0.5 & & & 3.6 & 0.2 & & \\
\hline Crab II & 0 & 107 & 1261 & 60 & & & 36.7 & 2.5 & & & 8.6 & 0.8 & & & 5.5 & 0.4 & & \\
\hline
\end{tabular}


quantify biomass losses during successive moults. Since a minimum of $0.2 \mu \mathrm{g}$ dry mass is needed for each elemental analysis, 20 exuviae (originating from various females) per replicate sample were pooled.

Weight measurements were carried out to the nearest $0.1 \mu \mathrm{g}$ with an autobalance (Mettler, UMT 2). Techniques and equipment used for obtaining $\mathrm{C}, \mathrm{N}$ and $\mathrm{H}$ content of larvae and young crabs are described by Anger and Harms (1990): short rinsing in distilled water, blotting on fluff-free Kleenex paper for optical use, freezing at $-18{ }^{\circ} \mathrm{C}$, vacuum drying at $<10^{-2}$ mbar, weighing and combusting at $1020{ }^{\circ} \mathrm{C}$ in a Fison Carlo Erba 1108 Elemental Analyser.

\subsection{Statistical treatments}

For both treatments (with and without Artemia provided as an external food supply), changes in biomass parameters $(W, \mathrm{C}, \mathrm{N}, \mathrm{H})$ were described and compared with linear regressions as functions of larval age (Sokal and Rohlf, 1995). The data were first logtransformed to achieve normality and homoscedasticity (tested with KolmogorovSmirnov and Bartlett's tests, respectively). Since biomass measurements for the developmental phases zoea-megalopa and megalopa-crab II were done with larvae obtained from the same female but hatched on different days, results and statistical analyses were carried out separately for each phase. Slope parameters of linear regressions obtained from treatments with and without feeding were compared an analysis of covariance (ANCOVA; Sokal and Rohlf, 1995). Where average values with error estimates are given in the text or in figures and tables, these represent arithmetic mean values \pm one standard deviation (S.D.).

\section{Results}

\subsection{Larval development}

The zoea I took on average about 4, the zoea II 7, and the zoea III 10-11 days. Most of the larval development time was spent in the megalopa, lasting $42-50$ days. The absence or presence of food did not influence development duration or survival, and corresponding results are reported elsewhere (Calcagno et al., submitted for publication a,b).

\subsection{Dry mass, percentage $C, N$ and $H$, and $C: N$ ratio}

Dry mass $(W)$ decreased continuously from hatching to metamorphosis, regardless of food availability (Table 1; Figs. 1 and 2). Near the end of the megalopa stage (day 40 within this stage, 62 days after hatching), the average $W$ of fed or unfed individuals amounted to about $73-75 \%$ of the initial value measured at hatching. The proportional losses of the elements $\mathrm{C}$ and $\mathrm{H}$ (predominantly bound in organic compounds) were, in general, higher than those of total $W$ and, as a consequence, their percentage values of $W$ decreased significantly throughout larval development, with or without food (Table 1). The $\mathrm{C}$ fraction decreased from initially $54 \%$ to about $36 \%$ of $W, \mathrm{H}$ from $8 \%$ to $5 \%$ of $W$. 


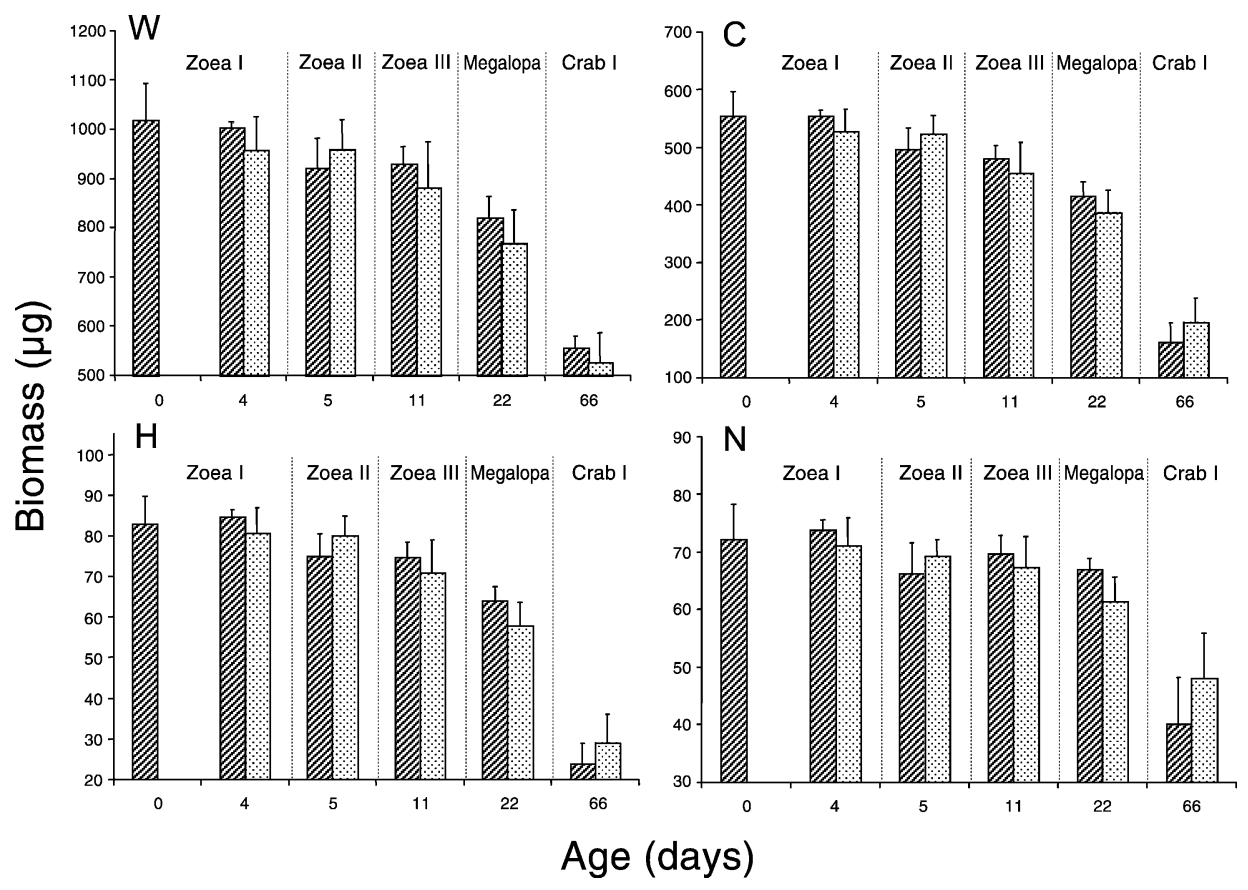

Fig. 1. L. santolla. Changes in dry mass $(W)$ and contents of carbon $(\mathrm{C})$, nitrogen $(\mathrm{N})$ and hydrogen $(\mathrm{H})(\mathrm{all}$ in $\mu \mathrm{g} /$ individual; $\bar{x}+$ S.D.) during larval development from hatching to metamorphosis in the presence or absence of food (Artemia sp.). Striped bars = with Artemia; dotted bars $=$ without Artemia . Sample size $=5$.

In contrast to the percentage $\mathrm{C}$ and $\mathrm{H}$ values, the percentage $\mathrm{N}$ remained stable or increased slightly, indicating that this fraction changed in approximately the same proportions as total $W$. As a consequence of consistently higher losses in $\mathrm{C}$ as compared to $\mathrm{N}$, the $\mathrm{C}: \mathrm{N}$ mass ratio, which may be used as an indicator of the lipid/protein ratio, decreased significantly during larval development (Fig. 4). Very high C:N values were measured at hatching $(7.7 \pm 0.2)$, while significantly lower values occurred shortly before metamorphosis $(4.4 \pm 0.2$ to $4.5 \pm 0.1$, in unfed and fed individuals, respectively). These patterns indicate a significant extent of lipid utilization throughout the course of larval development. Again, no influence of the presence or absence of food was apparent.

First feeding was consistently observed immediately after metamorphosis to the first juvenile crab stage, and this behavioural change was soon reflected in rapidly increasing dry mass values (Table 1; Fig. 3). However, $W$ increased significantly only during the first ca. 25 days of the first juvenile moulting cycle; thereafter, it remained almost constant. Due to the loss of a comparably heavy exuvia (see below), the freshly moulted crab II instar showed a conspicuously lower dry mass than the late crab I (Fig. 3).

The percentage values of $\mathrm{C}, \mathrm{N}$ and $\mathrm{H}$ within total $W$ decreased rapidly during the initial period (postmoult) of the crab I moulting cycle (Table 1). Since the absolute values of 


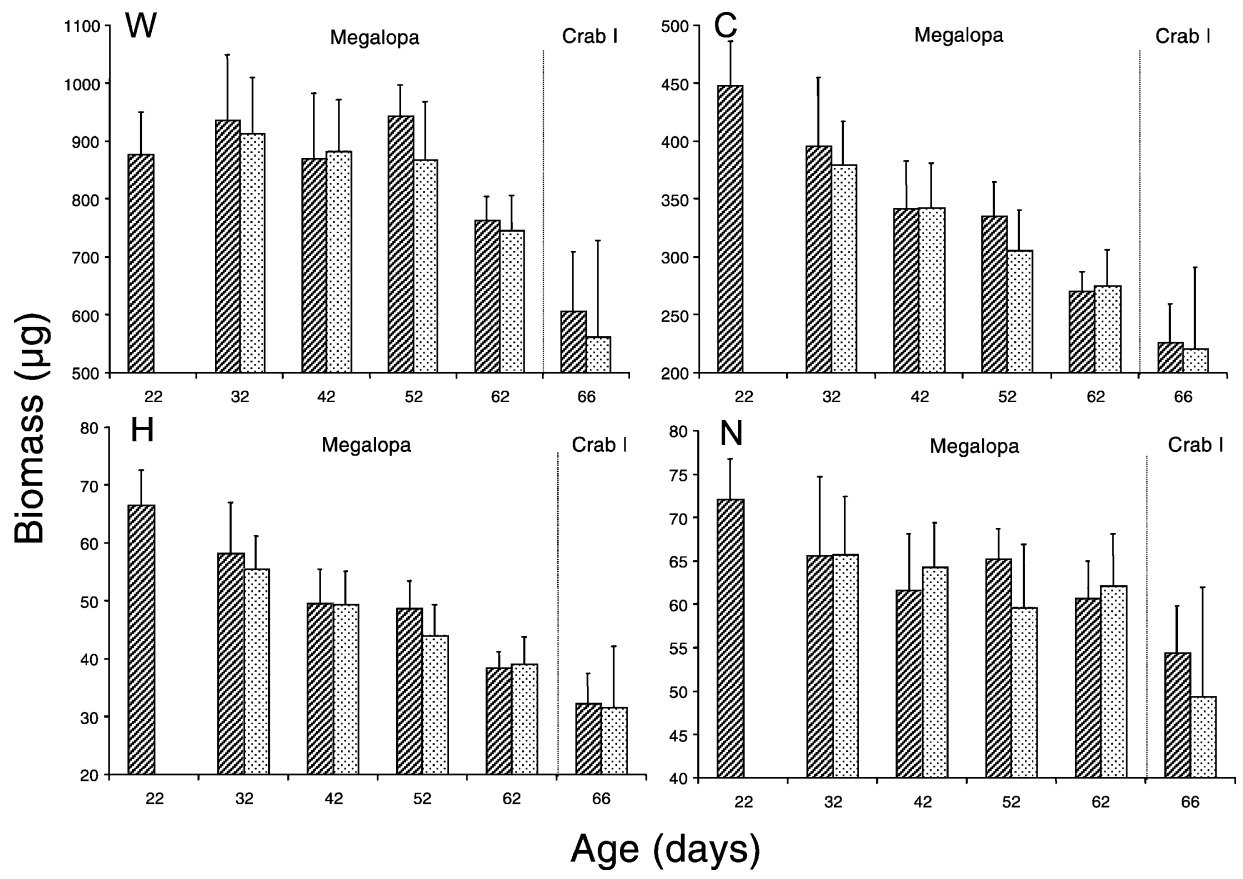

Fig. 2. L. santolla. Changes in dry mass $(W)$ and contents of carbon $(\mathrm{C})$, nitrogen $(\mathrm{N})$ and hydrogen $(\mathrm{H})(\mathrm{all}$ in $\mu \mathrm{g} /$ individual; $\bar{x}+$ S.D.) during megalopal development in the presence or absence of food (Artemia sp.). Striped bars $=$ with Artemia ; dotted bars $=$ without Artemia. Sample size $=5$.

these elements per individual increased (see below), decreasing percentage values indicate that total $W$ (including the mineral fraction) increased initially faster than the organic fraction of biomass. Later during the moulting cycle, the percentage values of $\mathrm{C}, \mathrm{N}$ and $\mathrm{H}$ increased slightly or remained constant (Table 1).

Also the average $\mathrm{C}: \mathrm{N}$ mass ratio increased rapidly during the postmoult phase of the first juvenile stage, from an initial value of $4.8 \pm 0.3$ to a maximum of $5.9 \pm 0.2$ about 10 days after metamorphosis. This increase was followed by slightly decreasing values in premoult (Fig. 4). A much lower value $(4.3 \pm 0.1)$ was found in the freshly moulted crab II stage.

\subsection{Organic biomass $(C, N, H)$ per individual}

The absolute contents of $\mathrm{C}, \mathrm{N}$ and $\mathrm{H}$ (in $\mu \mathrm{g}$ /individual), which are considered as measures of chiefly organic biomass, changed during the time of larval and early juvenile development with similar patterns as total dry mass $(W)$ (Figs. 1-3). The rates of change, however, in $\mathrm{C}$ and $\mathrm{H}$ were generally higher than in $W$ and in $\mathrm{N}$. When biomass values in a late megalopa (40 days) are compared with those measured immediately after hatching of the zoea I, differential degrees of utilization can be seen in the various measures biomass. While only about $26 \%$ of the initially present total $W$ 


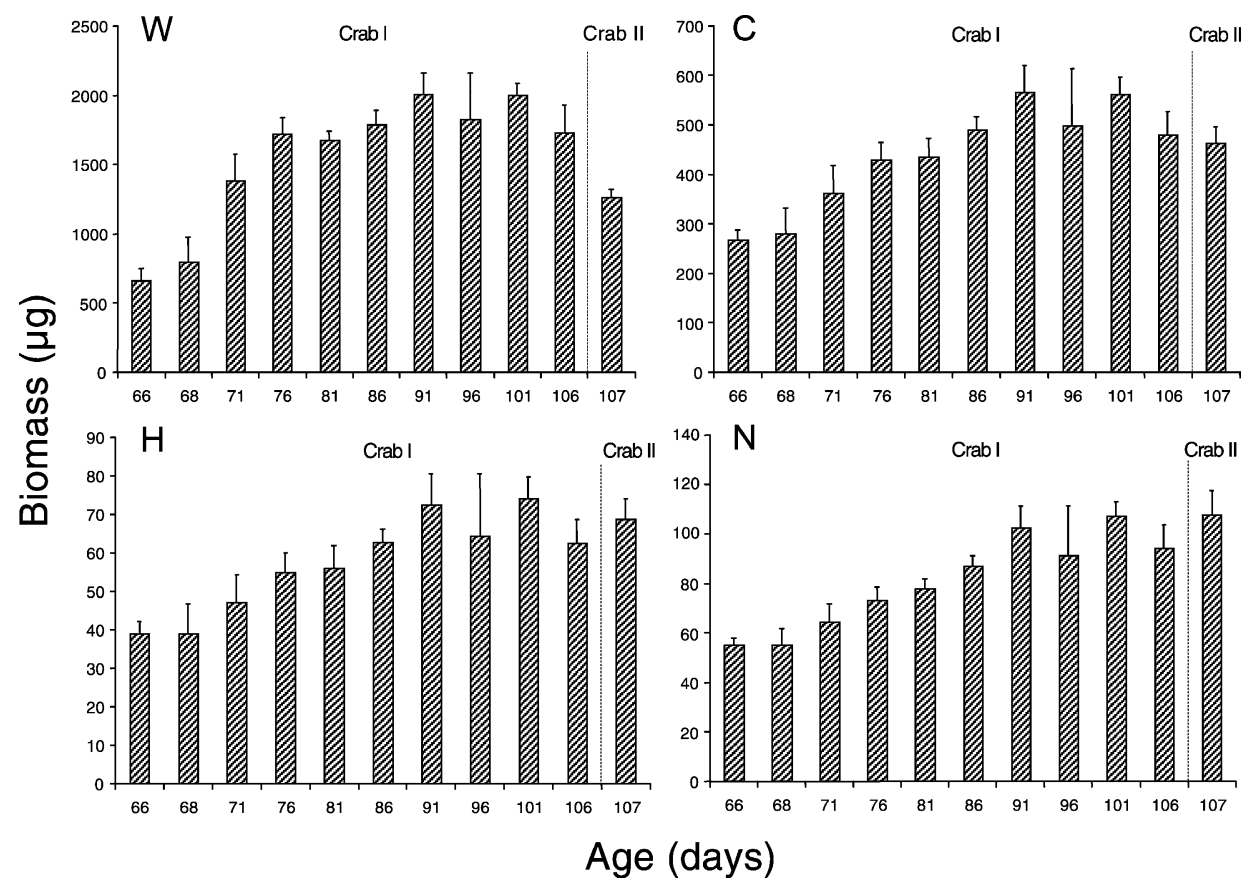

Fig. 3. L. santolla. Changes in dry mass $(W)$ and contents of carbon $(\mathrm{C})$, nitrogen $(\mathrm{N})$ and hydrogen $(\mathrm{H})($ all in $\mu \mathrm{g} /$ individual; $\bar{x}+$ S.D.) during early juvenile development. Sample size $=5$.

and $15 \%$ of $\mathrm{N}$ were lost during this developmental period (62 days from hatching), more than one half of the $\mathrm{C}$ and $\mathrm{H}$ fractions had disappeared concomitantly $(51 \%$ and $54 \%$, respectively). These losses include both the previous exuvial losses of the zoeal stages (but not yet that of the megalopa) and the metabolic degradation of organic substrates, which will be considered below.

Individual larval biomass decreased in a gradual manner. After logarithmic transformation of both the biomass and time data (the latter transformed to days +1 in order to exclude zero values), these patterns of change in biomass could be described as linear functions of the time of development (Table 2). Statistical comparison of the slope parameters by means of an ANCOVA did not reveal significant differences in any measure of biomass of fed and unfed larvae. This corroborates again our inference that all larval stages of L. santolla are fully lecithotrophic and nonfeeding also in the presence of a planktonic food source.

From metamorphosis until day 25 of its moulting cycle, the first juvenile crab instar (always fed with Artemia) showed a continuous and significant increase in all measures of individual biomass (Fig. 3). During this period (postmoult and early intermoult), the biomass of a crab I increased on average about three times in total dry mass and to almost double the initial contents of $\mathrm{C}, \mathrm{N}$ and $\mathrm{H}$. The proportionally higher increase in $W$ reflects the postmoult mineralization of the exoskeleton with inorganic constituents. 


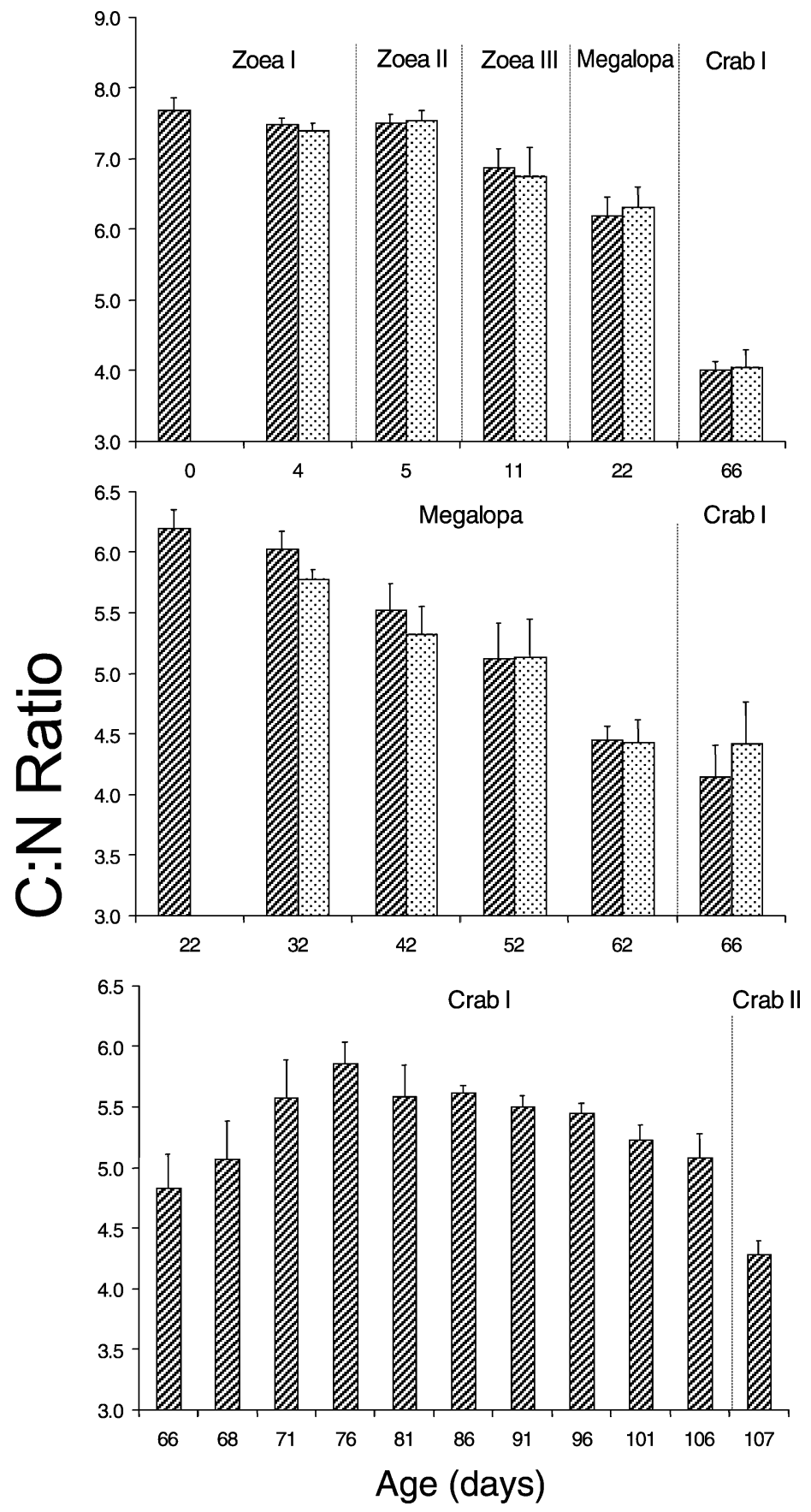

Fig. 4. L. santolla. Carbon/nitrogen (C:N) mass ratio during larval and early juvenile development. Striped bars $=$ with Artemia , dotted bars $=$ without Artemia . Sample size $=5$. 
Table 2

L. santolla. Parameters of linear regressions describing changes in dry mass $(W)$, contents of carbon $(\mathrm{C})$, nitrogen (N) and hydrogen $(\mathrm{H})$ (all in $\mu \mathrm{g}$ /individual), and in the $\mathrm{C}: \mathrm{N}$ mass ratio (all after logarithmic transformation) as functions of the time of development (transformation: $\log$ days +1 ) during two developmental periods (zoea IIII, megalopa) and in two treatments (with, without food, Artemia sp.)

\begin{tabular}{|c|c|c|c|c|c|c|c|c|}
\hline \multirow[t]{2}{*}{ Stage } & \multirow[t]{2}{*}{ Biomass parameter } & \multicolumn{3}{|c|}{ With food } & \multicolumn{3}{|c|}{ Without food } & \multirow[t]{2}{*}{$P$} \\
\hline & & Slope & Intercept & $r^{2}$ & Slope & Intercept & $r^{2}$ & \\
\hline \multirow[t]{5}{*}{ Zoea I-III } & $W$ & -0.004 & 3.005 & 0.606 & -0.006 & 3.005 & 0.612 & 0.183 \\
\hline & $\mathrm{C}$ & -0.006 & 2.745 & 0.718 & -0.007 & 2.747 & 0.710 & 0.187 \\
\hline & $\mathrm{H}$ & -0.005 & 1.923 & 0.649 & -0.008 & 1.930 & 0.709 & 0.076 \\
\hline & $\mathrm{N}$ & -0.001 & 1.854 & 0.070 & -0.003 & 1.860 & 0.420 & 0.074 \\
\hline & $\mathrm{C}: \mathrm{N}$ & -0.004 & 0.891 & 0.891 & -0.004 & 0.887 & 0.780 & 0.518 \\
\hline \multirow[t]{5}{*}{ Megalopa } & $W$ & -0.003 & 3.045 & 0.305 & -0.004 & 3.067 & 0.313 & 0.513 \\
\hline & $\mathrm{C}$ & -0.006 & 2.787 & 0.762 & -0.006 & 2.788 & 0.644 & 0.787 \\
\hline & $\mathrm{H}$ & -0.006 & 1.968 & 0.771 & -0.007 & 1.967 & 0.659 & 0.810 \\
\hline & $\mathrm{N}$ & -0.002 & 1.892 & 0.361 & -0.003 & 1.918 & 0.319 & 0.364 \\
\hline & $\mathrm{C}: \mathrm{N}$ & -0.004 & 0.895 & 0.889 & -0.003 & 0.869 & 0.865 & 0.148 \\
\hline
\end{tabular}

$r^{2}$ : coefficient of determination; all slopes are significantly different from zero $(P<0.001)$; the slopes of regressions obtained from the different treatments do not differ significantly from each other (ANCOVA: all $P>0.05)$.

\subsection{Exuvial losses}

The biomass and elemental composition of larval exuviae is shown in Table 3. Due to technical difficulties obtaining a sufficiently high number of complete larval exuviae for analyses (these rapidly fall apart), there is a great deal of variability in our data, in particular in those of zoea II exuviae. Yet, the average values allow for comparing chemical traits of the exuviae with those of whole-body biomass and for estimating exuvial losses in relation to other (metabolic) losses of organic biomass.

Total dry mass and contents of $\mathrm{C}, \mathrm{N}$ and $\mathrm{H}$ per exuvia were generally low and similar among the three zoeal stages, while significantly higher values were found in the

Table 3

L. santolla. Dry mass $(W)$, contents of carbon $(\mathrm{C})$, nitrogen $(\mathrm{N})$ and hydrogen $(\mathrm{H})$ (all in $\mu \mathrm{g} /$ individual and in $\%$ of $W$ ), and $\mathrm{C}: \mathrm{N}$ mass ratio of the exuviae of all larval stages and the first juvenile crab; $\bar{x} \pm$ S.D.

\begin{tabular}{|c|c|c|c|c|c|c|c|c|c|c|c|}
\hline \multirow[t]{2}{*}{ Stage } & & \multicolumn{2}{|l|}{$W$} & \multicolumn{2}{|l|}{$\mathrm{C}$} & \multicolumn{2}{|l|}{$\mathrm{N}$} & \multicolumn{2}{|l|}{$\mathrm{H}$} & \multicolumn{2}{|c|}{$\mathrm{C}: \mathrm{N}$ mass ratio } \\
\hline & & $\overline{\bar{x}}$ & \pm S.D. & $\overline{\bar{x}}$ & \pm 土 S.D. & $\bar{x}$ & \pm S.D. & $\bar{x}$ & \pm S.D. & $\bar{x}$ & \pm S.D. \\
\hline \multirow[t]{2}{*}{ Zoea I } & $\mu \mathrm{g} /$ ind & 37 & 5 & 8.5 & 0.6 & 1.7 & 0.1 & 1.2 & 0.1 & & \\
\hline & $\%$ of $W$ & & & 23.7 & 2.2 & 4.6 & 0.4 & 3.4 & 0.2 & 5.2 & 0.1 \\
\hline \multirow[t]{2}{*}{ Zoea II } & $\mu \mathrm{g} / \mathrm{ind}$ & 32 & 10 & 5.9 & 0.6 & 0.8 & 0.2 & 0.8 & 0.1 & & \\
\hline & $\%$ of $W$ & & & 19.0 & 3.7 & 2.7 & 1.3 & 2.7 & 0.8 & 8.1 & 3.5 \\
\hline \multirow[t]{2}{*}{ Zoea III } & $\mu \mathrm{g} /$ ind & 33 & 3 & 7.3 & 0.4 & 1.3 & 0.0 & 1.1 & 0.1 & & \\
\hline & $\%$ of $W$ & & & 22.2 & 1.0 & 3.9 & 0.3 & 3.4 & 0.1 & 5.7 & 0.2 \\
\hline \multirow[t]{2}{*}{ Megalopa } & $\mu \mathrm{g} /$ ind & 182 & 15 & 26.9 & 1.8 & 3.5 & 0.2 & 3.8 & 0.3 & & \\
\hline & $\%$ of $W$ & & & 14.8 & 0.6 & 1.9 & 0.2 & 2.1 & 0.1 & 7.8 & 0.4 \\
\hline \multirow[t]{2}{*}{ Crab I } & $\mu \mathrm{g} /$ ind & 922 & 117 & 128.0 & 13.6 & 7.7 & 0.9 & 8.4 & 1.0 & & \\
\hline & $\%$ of $W$ & & & 13.9 & 0.5 & 0.8 & 0.1 & 0.9 & 0.0 & 10.7 & 0.7 \\
\hline
\end{tabular}


megalopa and crab I stages. The megalopa lost its exuvia at metamorphosis with similar or higher amounts of biomass than all zoeal stages combined, and the first juvenile crab lost more exuvial matter (especially $W$ and $\mathrm{C}$ ) than all larval stages (i.e. all zoeal stages and the megalopa) combined.

As a striking feature of the exuviae, the percentage $\mathrm{C}, \mathrm{N}$ and $\mathrm{H}$ values (in $\%$ of $W$ ) were, in general, far below those of whole-body biomass, while the exuvial $\mathrm{C}: \mathrm{N}$ mass ratio was mostly higher than in entire larval and early juvenile bodies (cf. Table 1). When exuviae of successive developmental stages are compared, a decreasing trend can be seen in the percentage $\mathrm{C}, \mathrm{N}$ and $\mathrm{H}$ values, while the $\mathrm{C}: \mathrm{N}$ ratio tended to increase.

Exuvial losses may be considered in relation to the larval or juvenile biomass reached shortly before ecdysis. Since the zoeal stages produced very thin and fragile exuviae with low contents of $\mathrm{C}, \mathrm{N}$ and $\mathrm{H}$, each of them lost only $3.4-3.8 \%$ of premoult dry mass and about $1-2 \%$ of premoult $\mathrm{C}, \mathrm{N}$ and $\mathrm{H}$. Much higher losses occurred in the megalopa, where $25 \%$ of premoult $W, 5 \%$ of $\mathrm{N}$, and $10 \%$ of $\mathrm{C}$ and $\mathrm{H}$ were lost. Yet higher losses were observed in the first juvenile crab stage which lost more than one half $(53 \%)$ of total premoult $W, 27 \%$ of $\mathrm{C}, 8 \%$ of $\mathrm{N}$, and $13 \%$ of $\mathrm{H}$.

In Fig. 5, exuvial losses are shown as percentage values of the initial biomass at hatching from the egg. This allows for separating exuvial from metabolic losses, which together are responsible for total losses occurring in individual biomass during the course of nonfeeding larval development. In the three zoeal stages combined, about $10 \%$ of the initial (posthatching) $W$ and $4-5 \%$ of the initially available $\mathrm{C}, \mathrm{N}$ and $\mathrm{H}$ were lost with the

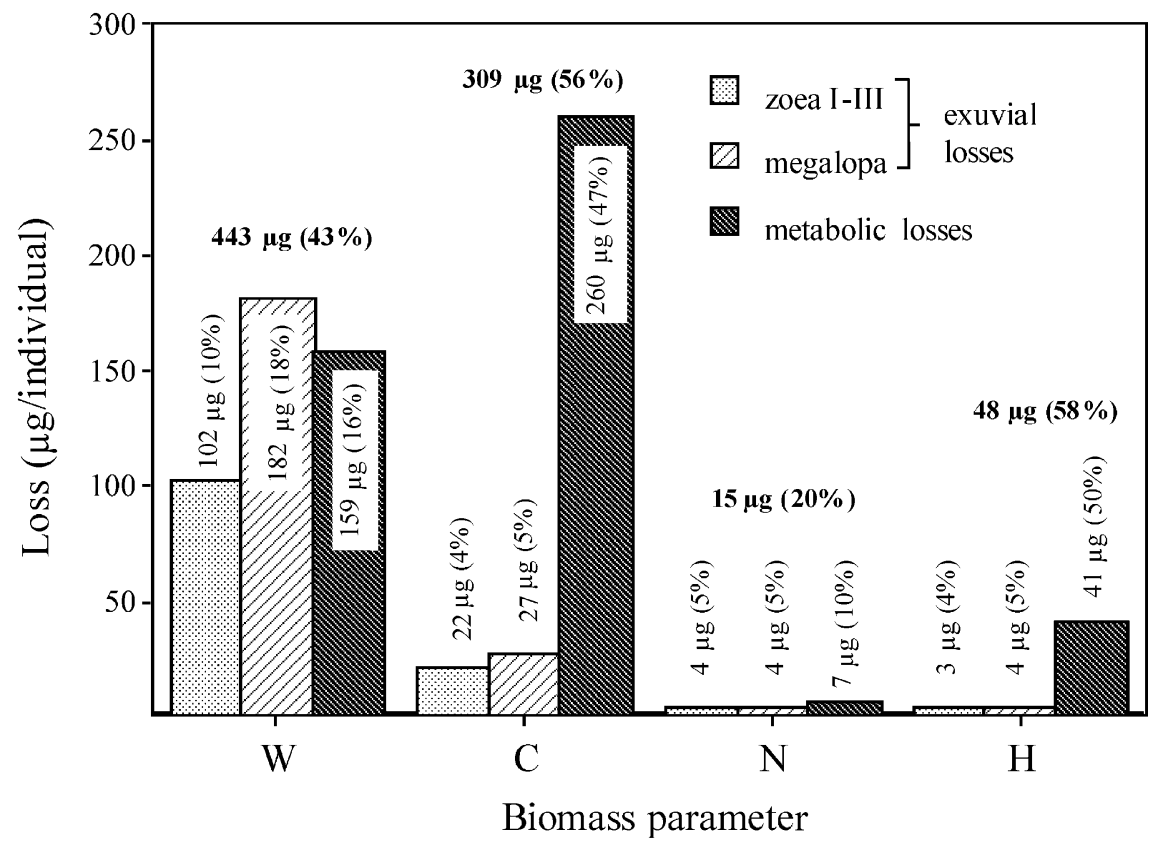

Fig. 5. L. santolla. Exuvial and metabolic losses of dry mass $(W)$, carbon $(\mathrm{C})$, nitrogen $(\mathrm{N})$ and hydrogen $(\mathrm{H})$ given in $\mu \mathrm{g} /$ individual and in $\%$ of the initially present biomass values at hatching. 
shed exuviae. Another $18 \%$ of initial $W$ and about $5 \%$ of $\mathrm{C}, \mathrm{N}$ and $\mathrm{H}$ were lost with the megalopal exuvia cast at metamorphosis.

Total losses of biomass during lecithotrophic larval development from hatching to metamorphosis, including the combined effects of exuviation and metabolism, can be estimated as the difference between the initial biomass measured immediately after hatching ( 0 days) and those of the late megalopa (day 40, or 62 days after hatching; see Table 1; Fig. 2) after subtracting from this the biomass of the megalopal exuvia (Table 3). In $W, \mathrm{C}, \mathrm{N}$ and $\mathrm{H}$, these total losses amounted to ca. 443, 309, 14 and 48 $\mu \mathrm{g} /$ individual, or $43 \%, 56 \%, 20 \%$ and $58 \%$ of the initial (posthatching) values, respectively. Within these losses, the cast exuviae (all larval stages combined) accounted for about two thirds of $W$ and one half of $\mathrm{N}$ lost from hatching to metamorphosis, while metabolic biomass degradation was responsible for most of the losses in $\mathrm{C}$ and $\mathrm{H}$ (Fig. 5).

\section{Discussion}

The patterns of larval and early juvenile development as well as changes in biomass and chemical composition observed in a Subantarctic king crab, L. santolla, can be compared with those previously described for a congener from the North Atlantic, L. maja (Anger, 1996). These two closely related but geographically separated subpolar species show a number of striking similarities not only in their adult ecology and climatic distribution but also in early development. Both pass through three zoeal stages and a megalopa, and comparison of development duration, larval survival, and changes in biomass and chemical composition of fed and unfed larvae shows that both species develop from hatching to metamorphosis completely independent from food. Total duration of larval development at $6{ }^{\circ} \mathrm{C}$ was about 10 weeks in L. santolla, while L. maja required about 7 weeks at a rearing temperature of $9{ }^{\circ} \mathrm{C}$. This suggests similarity also in the temperature dependence of development duration.

The most striking similarity between L. santolla and L. maja is in the complete lecithotrophy from hatching through all four larval stages to metamorphosis. Both species live in subpolar regions where strong seasonality in the light conditions allows for only a short period of primary production, while low average temperatures, even during summer, enforce a long duration of development. This mismatch of short planktonic food availability and long pelagic development in cold waters should have selected for a food-independent mode of larval development, which is principally based on an enhanced energy allocation to female reproduction (for recent discussion, see Anger, 2001). Lecithotrophy has recently been observed also in a congener from the North Pacific and the Bering Sea, the golden king crab, Lithodes aequispinus (Shirley and Zhou, 1997), which suggests that this may be a wide-spread developmental pattern in Lithodes species living in high latitudes.

An extremely high $\mathrm{C}: \mathrm{N}$ ratio (7.7) at hatching indicates that large lipid reserves persist in both species from the egg yolk, serving the larvae as an energy-rich fuel for endotrophic development under conditions of strongly limited food availability. In both species, the $\mathrm{C}: \mathrm{N}$ ratio decreased significantly during larval development, which indicates a preferential 
degradation of lipid reserves, especially during the zoeal (i.e. more active) phase of development, coinciding with a weaker decrease in the protein pool (cf. Anger, 1996). As another similarity between these species, the first juvenile crab stage showed immediately after metamorphosis food uptake and rapid growth. A particularly steep increase in the $\mathrm{C}: \mathrm{N}$ ratio during the postmoult and early intermoult periods suggests a rapid replenishment of lost lipids. In addition, however, cuticular mineralization with inorganic carbonates may contribute to this increase in the $\mathrm{C}: \mathrm{N}$ index. Decreasing values thereafter indicate in both species a proportionally stronger increase in the protein fraction, reflecting epidermal reconstruction and growth of muscular and nervous tissues during the premoult period. All these patterns are typical of planktotrophic larval and juvenile crab stages (for recent review, see Anger, 2001).

Besides the patterns of larval development and associated chemical changes within biomass, there are similarities in larval behaviour of these two Lithodes species. In the zoeal stages, both are slow but active swimmers, showing a tendency to stay near the bottom (demersal larvae). The same applies to the megalopa during the first $2-3$ days after moulting. Subsequently, however, the megalopa becomes fully benthic and increasingly sluggish. Low locomotory activity of the larvae may be an energy-saving mechanism during nonfeeding development, representing another possible adaptation to food-limited environments.

As an additional tentatively adaptive trait, the larval stages (in particular the zoeae) of both species show very low exuvial energy losses as compared with planktotrophic decapod larvae (for recent discussion of the literature, see Anger, 1996, 2001). Production of unusually thin exuviae was observed also in a terrestrial brachyuran crab species with nonfeeding larvae (Anger and Schuh, 1992), suggesting that similar energysaving traits may occur in various decapod crustacean taxa with a lecithotrophic mode of development.

Similar reproductive traits as in Lithodes spp. have recently been observed also in another Subantarctic lithodid species, the southern stone crab, Paralomis granulosa (Calcagno et al., submitted for publication a,b). This species shows a yet more abbreviated mode of development with only two zoeal stages and a megalopa. As in L. santolla and L. maja, its zoeae are demersal, while the megalopa is benthic and very inactive, and all larval stages are fully lecithotrophic. Likewise, endotrophic larval development is based on high initial energy stores remaining from the egg yolk (predominantly lipids), and a reduced locomotory activity and low exuvial losses of organic matter occur as putative energy-saving mechanisms. Together, these similarities suggest that such traits may be typical adaptations to conditions of short planktonic productivity in combination with low average temperatures in subpolar regions. Similar patterns may thus be expected to occur also in other lithodids from high latitudes, for instance, in L. aequispinus.

\section{Acknowledgements}

We greatly appreciate the help of the crew of PFS Polarstern during the transport of live king crabs. Special thanks are due to C. Püschel for elemental analyses. A. Chizzini and F. 
Tapella helped in capturing specimens in the Beagle Channel. E. Heyer and R. Hottung helped in maintaining larval cultures. J. Calcagno is grateful to the German Academic Exchange Service (DAAD) for funding his research visit to Helgoland. This project was funded by the International Bureau of the German Ministry of Scientific Research (BMBF, project no. ARG 99/002), and the Argentine Secretaría Nacional para la Tecnología, Ciencia e Inovación Productiva (SETCIP). [SS]

\section{References}

Amin, O.A., Rodríguez, E.M., Hernando, M., Comoglio, L.I., Lopez, L.S., Medesani, D.A., 1998. Effects of lead and cadmium on hatching of the southern king crab Lithodes santolla (Decapoda, Anomura). Invertebr. Reprod. Dev. 33, 81-85.

Anger, K., 1996. Physiological and biochemical changes during lecithotrophic larval development and early juvenile growth in the northern stone crab, Lithodes maja (Decapoda: Anomura). Mar. Biol. 126, 283-296.

Anger, K., 2001. The biology of decapod crustacean larvae. Crustacean Issue 14. A.A. Balkema Publishers, Swets and Zeitlinger, Lisse, ISSN 0168-6456, pp. 1-420.

Anger, K., Harms, J., 1990. Elemental (CHN) and proximate biochemical composition of decapod crustacean larvae. Comp. Biochem. Physiol. 97B, 69-80.

Anger, K., Schuh, M., 1992. Bioenergetics of abbreviated larval development in the bromelid crab, Metopaulias depressus (Decapoda: Grapsidae). Comp. Biochem. Physiol. 103A, 507-518.

Calcagno, J.A., Kaffenberger, A., Lovrich, G.A., Thatje, S., Anger, K., submitted for publication (a). Larval development of the subantarctic king crabs Lithodes santolla and Paralomis granulosa reared in the laboratory. Helgol. Mar. Res.

Calcagno, J.A., Thatje, S., Anger, K., Lovrich, G.A., Kaffenberger, A., submitted for publication (b). Changes in biomass and chemical composition during lecithotrophic larval development of the Southern stone crab, Paralomis granulosa (Jacquinot). Mar. Ecol. Prog. Ser.

Campodonico, I., 1971. Desarrollo larval de la centolla Lithodes antarctica Jacquinot en condiciones de laboratorio (Crustacea Decapoda, Anomura: Lithodidae). An. Inst. Patagon., Ser. Cienc. Nat. (Punta Arenas, Chile) 2, 181-190.

Comoglio, L., Vinuesa, J., 1991. Larval culture of southern king crab Lithodes santolla and false king crab Paralomis granulosa under laboratory conditions. In: Jaspers, E., Ollevier, F. (Eds.), LARVI '91, Fish and Crustacean Larviculture Symposium. In: Lavens, P., Sorgeloos, P. (Eds.), European Aquaculture Society, Spec. Publ., vol. 15, pp. 349-351. Gent, Belgium.

Dawson, E.W., 1989. King crabs of the world (Crustacea: Lithodidae) and their fisheries: a comprehensive bibliography. Misc. Publ., vol. 101. New Zealand Oceanogr. Inst., Div. Water Sci., DSIR, Wellington.

Lovrich, G.A., 1997. La pesquería mixta de las centollas Lithodes santolla y Paralomis granulosa (Anomura: Lithodidae) en Tierra del Fuego, Argentina. Investig. Mar. (Valparaíso) 25, 41-57.

Lovrich, G.A., 1999. Seasonality of larvae of Brachyura and Anomura (Crustacea Decapoda) in the Beagle Channel, Argentina. Sci. Mar. (Suppl. 1), 347-354.

Lovrich, G.A., Vinuesa, J.H., 1996. Reproductive strategies of two lithodids in the Beagle Channel, Argentina: a complementary management tool in a changing fishery. In: Baxter, B. (Ed.), High Latitude Crabs: Biology, Management, and Economics. University of Alaska, Fairbanks, AK, pp. 333-340. Alaska Sea Grant College Program No. 96-02.

Lovrich, G.A., Vinuesa, J.H., 1999. Reproductive potential of the lithodids Lithodes santolla and Paralomis granulosa (Anomura, Decapoda) in the Beagle Channel, Argentina. Sci. Mar. 63 (Suppl. 1), 355-360.

McLaughlin, P.A., Anger, K., Kaffenberger, A., Lovrich, G.A., 2001. Megalopal and early juvenile development in Lithodes santolla (Molina, 1782) (Decapoda: Anomura; Paguroidea: Lithodidae), with notes on zoeal variations. Invertebr. Reprod. Dev. 40, 53-67.

Nakanishi, T., 1985. The effects of the environment on the survival rate, growth and respiration of eggs, larvae and post-larvae of king crab (Paralithodes camtschaticus). Proc. Int. King Crab Symp., University of Alaska, Anchorage, AK, pp. 167-185. Alaska Sea Grant Rep. No. 85-12. 
Shirley, T.C., Zhou, S., 1997. Lecithotrophic development of the golden king crab Lithodes aequispinus (Anomura: Lithodidae). J. Crustacean Biol. 17, 207-216.

Sokal, R.R., Rohlf, F.J., 1995. Biometry, The Principles and Practice of Statistics in Biological Research. Freeman, New York, NY. 887 pp.

Vinuesa, J.H., Ferrari, L., Lombardo, R.J., 1985. Effect of temperature and salinity on larval development of southern king crab (Lithodes antarcticus). Mar. Biol. 85, 83-87. 